Pregledni rad

https://doi.org/10.31784/zvr.7.1.17

Datum primitka rada: 15. 1. 2019.

Datum prihvaćanja rada: 1. 3. 2019.

\title{
KRETANJE OSOBNE POTROŠNJE NA PRIMJERU ODABRANIH ČLANICA EU-A
}

\author{
Vesna Buterin \\ Dr. sc., docent, Sveučilište u Rijeci, Ekonomski fakultet, Ivana Filipovića 4, 51000 Rijeka, \\ Hrvatska; e-mail: vesna.buterin@efri.hr
}

Nela Vlahinić Lenz

Dr. sc., redoviti profesor, Sveučilište u Rijeci, Ekonomski fakultet, Ivana Filipovića 4, 51000 Rijeka, Hrvatska; e-mail: nela.vlahinic.lenz@efri.hr

\section{Natalija Mihaljević}

Studentica, Sveučilište u Rijeci, Ekonomski fakultet, Ivana Filipovića 4, 51000 Rijeka, Hrvatska; e-mail: natalija377@gmail.com

\section{SAŽETAK}

Osobna potrošnja najveći je makroekonomski agregat s velikim utjecajem na ekonomska kretanja i udjelom u BDP-u od oko $60 \%$. Cilj rada bio je utvrditi postoje li značajne razlike u kretanju i strukturi osobne potrošnje u Hrvatskoj i dvjema novim članicama EU-a, Češkoj i Rumunjskoj, te utvrditi obrasce promjena osobne potrošnje u promatranim državama. Analiza je potvrdila snažnu povezanost osobne potrošnje i BDP-a, a ta je veza donekle snažnija kod Rumunjske, gdje se smjer stopa promjena gotovo podudara. Navedeno potvrđuje osobnu potrošnju kao važnu kategoriju o kojoj treba voditi računa kod donošenja makroekonomskih politika. Analiza je također pokazala da je udio osobne potrošnje u BDP-u najmanji u Češkoj, što ukazuje na zaključak da postoje neki drugi pokretači češkog gospodarstva, prvenstveno investicije i neto izvoz. S obzirom na to da su Češka i Hrvatska male otvorene ekonomije koje su usporedive i po dostignutom stupnju razvoja, a imajući u vidu češki gospodarski rast koji je znatno viši nego u Hrvatskoj, može se zaključiti da je model gospodarskog rasta u Češkoj bolji i dugoročno održiviji. Oslanjanje gospodarskog rasta na osobnu potrošnju kao generator agregatne potražnje nije model koji može osigurati održiv rast BDP-a u Hrvatskoj, pogotovo u uvjetima smanjenja broja stanovnika. Stoga je nužno osigurati poticajan institucijski okvir za rast domaćih i inozemnih investicija te veću izvoznu orijentaciju.

Ključne riječi: osobna potrošnja, bruto domaći proizvod, ekonomski rast 


\section{UVOD}

Osobna potrošnja može se definirati kao ukupna vrijednost trošenja namijenjena tekućoj uporabi kućanstava za potrošnu robu i usluge. Osobna potrošnja predstavlja zbroj dobara i usluga koje su kupili rezidenti neke zemlje, odnosno domaći potrošači (Borozan, 2012), a često se smatra jednom od najvažnijih mjera ekonomskog uspjeha i jednom od ključnih determinanti životnog standarda (Osei Bonsu, Muzindutsi, 2017). Niska vrijednost osobne potrošnje po stanovniku, s njenim relativno većim udjelom u ostvarenom BDP-u, ukazuje na niži stupanj gospodarske razvijenosti zemlje. Na visokom stupnju gospodarske razvijenosti udio osobne potrošnje kreće se na razini od oko 60 \% BDP-a, a vrijednost osobne potrošnje po stanovniku značajno raste (Denona Bogović, 2002).

Granična sklonost potrošnji određena je derivacijom funkcije potrošnje po raspoloživom dohotku (Keynes, 1936). Premda agregatna potrošnja ima multiplikativne učinke na zaposlenost, investicije i štednju (Jurić, 2018), treba imati na umu da prevelika sklonost potrošnji može dovesti do problema poput siromaštva, neravnoteže bilanci i deficita (Rahim i Bahari, 2018). Zbog svog velikog udjela u BDP-u, osobna potrošnja važna je kod donošenja makroekonomskih politika (Pretorius, Knox, 1995).

Autorice u radu istražuju povezanost kretanja osobne potrošnje u Hrvatskoj uspoređujući ta kretanja s onima u Češkoj i Rumunjskoj. Sve tri promatrane države prošle su tranzicijski put, ali s bitno različitim razvojnim rezultatima. Autorice žele utvrditi postoje li značajne razlike u osobnoj potrošnji po stanovniku, kakav je udio osobne potrošnje u BDP-u te kako su se te veličine mijenjale tijekom gospodarske krize. Rad je podijeljen u pet poglavlja. Nakon Uvoda slijedi drugo poglavlje koje analizira specifičnosti ekonomske krize te njen utjecaj na osobnu potrošnju. Treće poglavlje analizira kretanje i strukturu osobne potrošnje, dok četvrto poglavlje promatra usporedno osobnu potrošnju i BDP te identificira modele gospodarskog rasta u tri analizirane države. Rezultati istraživanja o utjecaju osobne potrošnje na rast BDP-a sistematizirani su na kraju rada.

\section{UTJECAJ EKONOMSKE KRIZE NA BDP I OSOBNU POTROŠNJU}

Ekonomska kriza ili recesija započinje nakon što je stopa rasta bruto domaćeg proizvoda u dva uzastopna tromjesečna razdoblja zabilježila negativne vrijednosti, a predstavlja privremeno pogoršanje makroekonomskih pokazatelja, prije svega pad bruto domaćeg proizvoda koji je u pravilu praćen povećanjem nezaposlenosti, porastom nelikvidnosti, smanjenjem investicijske aktivnosti, padom cijena imovine i dr. Ekonomske krize karakterizira cikličnost, a vjerojatnost predviđanja početka nove krize smanjuje se s protekom vremena. lako su ekonomisti svjesni neminovnosti cikličkih kretanja u gospodarstvu, kako nacionalnom, tako i globalnom, ipak se može reći kako je početak ekonomske krize nepredviđeni događaj koji snažno utječe na ponašanje građana, odnosno na donošenje njihovih odluka o potrošnji. Ekonomska kriza ima utjecaj na osobnu potrošnju, osobito u dužem vremenskom periodu, jer potrošači ne doživljavaju krizu trenutačno, već s vremenom uočavaju promjene i mijenjaju svoje navike. Krizna razdoblja navode potrošače da donose racionalnije odluke o potrošnji i štednji, odnosno da manje troše i više štede. Zbog smanjenja raspoloživih dohodaka, dolazi i do smanjenja realne potrošnje kućanstva. U tablici 
1 prikazano je kretanje BDP-a u odabranim državama u apsolutnim iznosima, a u tablici 2 su za iste države prikazane stope rasta BDP-a u razdoblju od 2007. godine, kada je započela globalna recesija, pa sve do 2017. godine.

Tablica 1. Kretanje BDP-a u odabranim članicama EU-a od 2007. do 2017. godine u milijunima eura, tekuće cijene

\begin{tabular}{|c|c|c|c|}
\hline Država/godina & Češka & Hrvatska & Rumunjska \\
\hline 2007. & 138.303 & 43.926 & 128.618 \\
\hline 2008. & 161.313 & 48.130 & 146.106 \\
\hline 2009. & 148.682 & 45.091 & 124.141 \\
\hline 2010. & 156.718 & 45.128 & 125.736 \\
\hline 2011. & 164.041 & 44.808 & 132.590 \\
\hline 2012. & 161.434 & 43.996 & 133.511 \\
\hline 2013. & 157.742 & 43.725 & 144.254 \\
\hline $\mathbf{2 0 1 4 .}$ & 156.660 & 43.391 & 150.358 \\
\hline $\mathbf{2 0 1 5 .}$ & 168.473 & 44.522 & 160.314 \\
\hline $\mathbf{2 0 1 6 .}$ & 176.564 & 46.382 & 169.772 \\
\hline $\mathbf{2 0 1 7 .}$ & 192.017 & 48.677 & 187.868 \\
\hline
\end{tabular}

Izvor: EUROSTAT, obradile i prilagodile autorice

Temeljem prikazanih podataka može se zaključiti da je Hrvatska ostvarila najnepovoljnije rezultate. U promatranom razdoblju hrvatski BDP premašio je predkriznu 2008. godinu tek 2017. godine. U Rumunjskoj se to dogodilo znatno ranije, već 2014. godine, a u Češkoj, nakon ponovnog pada u razdoblju 2012. do 2014. godine, u 2015. godini slijedi oporavak i rast. Usporedba BDP-a 2017. godine u odnosu na 2007. godinu također ukazuje na vrlo nepovoljne rezultate za Hrvatsku. $U$ tom desetogodišnjem razdoblju BDP je porastao samo $11 \%$, za razliku od Češke koja je ostvarila rast od 39 \% i Rumunjske s rastom od čak $46 \%$. 
V. Buterin, N. Vlahinić Lenz, N. Mihaljević: Kretanje osobne potrošnje na primjeru odabranih članica... Zbornik Veleučilišta u Rijeci, Vol. 7 (2019), No. 1, pp. 271-285

Tablica 2. Stope rasta BDP-a u odabranim članicama EU-a od 2007. do 2017. godine u \%

\begin{tabular}{|c|c|c|c|}
\hline Država/godina & Češka & Hrvatska & Rumunjska \\
\hline 2007. & 5,6 & 5,2 & 6,9 \\
\hline 2008. & 2,7 & 2,1 & 8,3 \\
\hline 2009. & $-4,8$ & $-7,4$ & $-5,9$ \\
\hline 2010. & 2,3 & $-1,4$ & $-2,8$ \\
\hline 2011. & 1,8 & $-0,3$ & 2,0 \\
\hline 2012. & $-0,8$ & $-2,2$ & 1,2 \\
\hline 2013. & $-0,5$ & $-0,6$ & 3,5 \\
\hline 2014. & $-0,7$ & $-0,1$ & 3,1 \\
\hline 2015. & 5,3 & 2,3 & 4,0 \\
\hline 2016. & 2,6 & 3,2 & 4,8 \\
\hline 2017. & 4,4 & 2,8 & 6,9 \\
\hline \multicolumn{2}{|c|}{ Izvor: EUROSTAT, obradile i prilagodile autorice } \\
\hline
\end{tabular}

Zaustavljanje tijekova kapitala i smanjenje globalne potražnje doveli su do toga da je rast BDP-a u 2008. godini bio značajno manji nego u 2007. godini, ali još uvijek pozitivan. Recesija je započela 2009. godine, kada je došlo do pada BDP-a na razini cijele Europske unije i u gotovo svim njenim članicama. Češka tada bilježi pad od 4,8 \%, Rumunjska 5,9 \%, a Hrvatska bilježi najveći pad, od 7,4 \%. Hrvatska je ostvarila rast BDP-a tek u 2015. godini, zahvaljujući porastu, prvenstveno, vanjske potražnje i neto izvozu, a zatim i zbog povećanja investicija u fiksni kapital. Rast se nastavio i u 2016. i 2017. godini, ali taj je rast u Hrvatskoj značajno niži nego što je bio u Češkoj ili Rumunjskoj.

Vrlo važan makroekonomski pokazatelj je i BDP po glavi stanovnika, koji pokazuje prosječni životni standard u državi, a time i njezin stupanj razvijenosti. Tablica 3 prikazuje bruto domaći proizvod po glavi stanovnika u razdoblju od deset godina.

Tablica 3. BDP po stanovniku u odabranim članicama EU-a od 2007. do 2017. godine u eurima

\begin{tabular}{|c|c|c|c|}
\hline Država/godina & Češka & Hrvatska & Rumunjska \\
\hline 2007. & 13.400 & 10.200 & 6.200 \\
\hline 2008. & 15.500 & 11.200 & 7.100 \\
\hline 2009. & 14.200 & 10.500 & 6.100 \\
\hline 2010. & 14.900 & 10.500 & 6.200 \\
\hline 2011. & 15.600 & 10.500 & 6.600 \\
\hline 2012. & 15.400 & 10.300 & 6.700 \\
\hline 2013. & 15.000 & 10.300 & 7.200 \\
\hline
\end{tabular}




\begin{tabular}{|l|l|l|l|}
\hline 2014. & 14.900 & 10.200 & 7.500 \\
\hline 2015. & 16.000 & 10.600 & 8.100 \\
\hline 2016. & 16.700 & 11.100 & 8.600 \\
\hline 2017. & 18.100 & 11.700 & 9.600 \\
\hline
\end{tabular}

Nakon početnog smanjenja 2009. godine, BDP po stanovniku u Češkoj i Rumunjskoj značajnije je rastao nego u Hrvatskoj. Promjene kretanja BDP-a prikazane su i na grafikonu 1.

Grafikon 1. Kretanja BDP-a u odabranim članicama EU-a od 2007. do 2017. godine

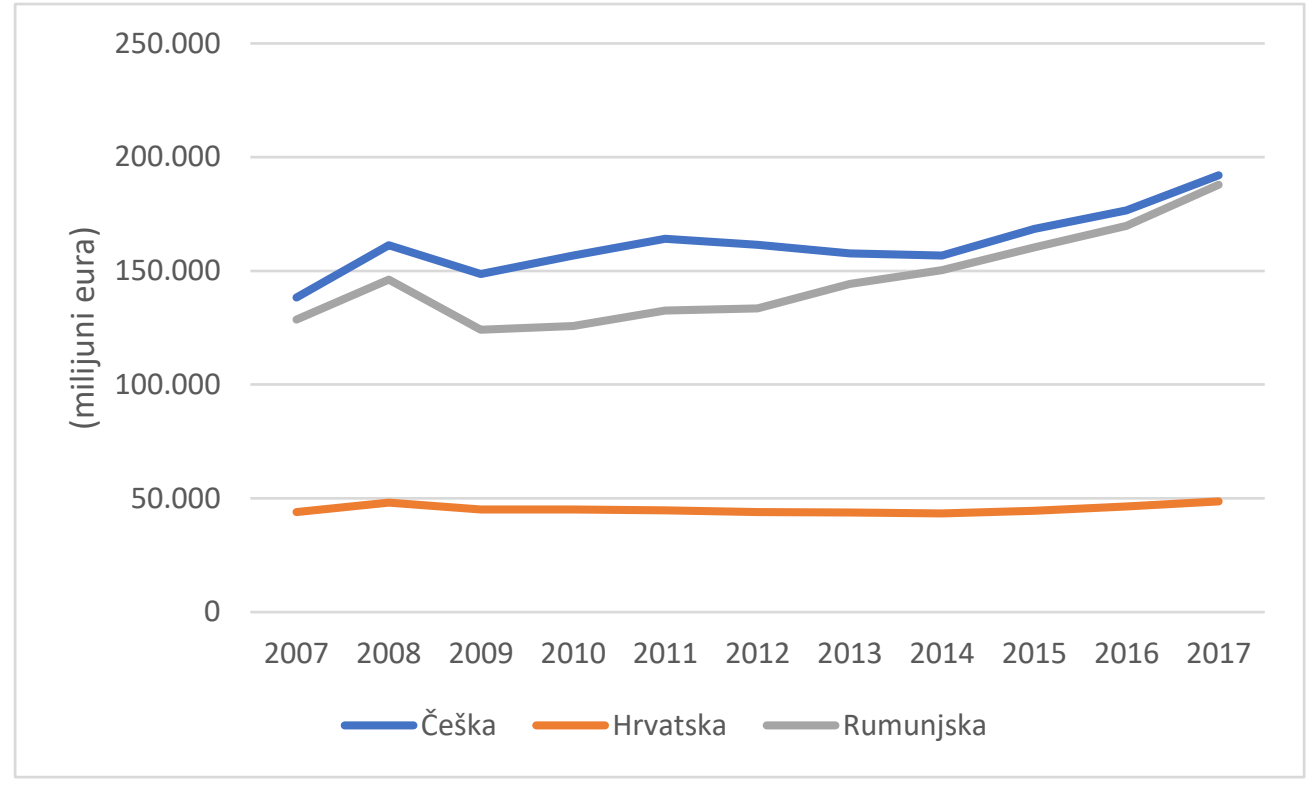

Izvor: EUROSTAT, obradile i prilagodile autorice

Podaci potvrđuju prethodnu analizu i dodatno naglašavaju stagnaciju hrvatskog gospodarstva. lako su sve države EU-a s izuzetkom Poljske proživjele recesiju, neke kraću, a neke dublju, potaknutu vlastitim strukturnim problemima, poseban problem u Hrvatskoj je trajanje recesije i izostanak strukturnih promjena. Hrvatska je jedina država u okruženju u kojoj je recesija trajala dugih šest godina. Naime, strukturne promjene rezultiraju dinamikom i bržim izlaskom iz recesije, dok je u Hrvatskoj puno toga ostalo nepromijenjeno, uključujući i razinu bruto domaćeg proizvoda. Upravo je izostanak strukturnih reformi najveći gospodarski problem, zbog čega nisu stvoreni odgovarajući temelji za brži ekonomski rast u budućnosti. 


\section{ANALIZA KRETANJA I STRUKTURE OSOBNE POTROŠNJE U RH I ODABRANIM ČLANICAMA EU-A}

Prethodna analiza pokazala je da su duga recesija te spori oporavak BDP-a najveći problemi hrvatskog gospodarstva, iz čega proizlaze brojne implikacije. Važna posljedica je, naravno, stagnacija osobne potrošnje koja u maloj zemlji kao što je Hrvatska nije mogla značajnije potaknuti domaću potražnju i ekonomski rast. Kao što je već napomenuto, uzroci hrvatske krize nisu samo u prelijevanju učinaka svjetske krize, već i u dubokim strukturnim problemima kao što su nekonkurentnost, neefikasnost države i institucija, rigidno tržište rada itd. Jedan od uzroka je i odnos duga i dohotka pravnih i fizičkih osoba. Njihova visoka zaduženost dovela je do pada kupovne moći u Hrvatskoj, što je dovelo do pada potrošnje, pa tako i uvoza. Nedostatak novca u 2008. i 2009. godini prouzročio je smanjenje kreditnih aktivnosti, što u konačnici dovodi do pada sklonosti potrošnji i do pada osobne potrošnje (Jurčić, 2017). Gospodarska kriza uzrokovala je pogoršanje gotovo svih makroekonomskih pokazatelja u RH. Izostanak oblikovanja i provedbe dugoročnih strateških ciljeva u ključnim gospodarskim područjima dovelo je do stvaranja ograničenja snažnijeg oporavka hrvatskog gospodarstva (Moorei, Vamvakidis, 2008). Gospodarska kriza dovela je i do pada potražnje na inozemnim tržištima, što je negativno utjecalo na izvozni sektor i proizvodnju, no $s$ vremenom je oporavak inozemne potražnje ipak potaknuo rast hrvatskog izvoza koji počinje značajnije rasti 2014. godine. Recesija je, ipak, najviše utjecala na pad investicijske aktivnosti. Udio investicija u BDP-u se u razdoblju od 2008. do 2014. godine smanjio s 28,1 \% na $19 \%$, što je snažno utjecalo na smanjenje proizvodnje i stope zaposlenosti. Sve su to razlozi zašto je recesija u Hrvatskoj potrajala sve do 2014. godine, dok u većini europskih država recesija prestaje u 2010. i 2011. godini (Buturac, 2017).

Tablica 4. Vrijednosti osobne potrošnje u odabranim članicama EU-a od 2007. do 2017. godine, u tekućim cijenama (milijunima eura)

\begin{tabular}{|c|c|c|c|}
\hline Država/godina & Češka & Hrvatska & Rumunjska \\
\hline 2007. & 63.703 & 25.753 & 86.678 \\
\hline 2008. & 76.413 & 27.984 & 93.060 \\
\hline 2009. & 72.279 & 26.334 & 77.008 \\
\hline 2010. & 76.725 & 26.528 & 79.248 \\
\hline 2011. & 80.469 & 26.699 & 83.045 \\
\hline 2012. & 79.436 & 26.431 & 84.313 \\
\hline 2013. & 77.946 & 26.249 & 87.966 \\
\hline 2014. & 75.307 & 25.515 & 92.717 \\
\hline 2015. & 78.895 & 25.743 & 99.084 \\
\hline 2016. & 82.920 & 26.590 & 106.430 \\
\hline $\mathbf{2 0 1 7 .}$ & 90.720 & 28.059 & 117.546 \\
\hline
\end{tabular}

Izvor: EUROSTAT, obradile i prilagodile autorice 
Grafikon 2. Vrijednosti osobne potrošnje u odabranim članicama EU-a od 2007. do 2017. godine, u tekućim cijenama (milijunima eura)

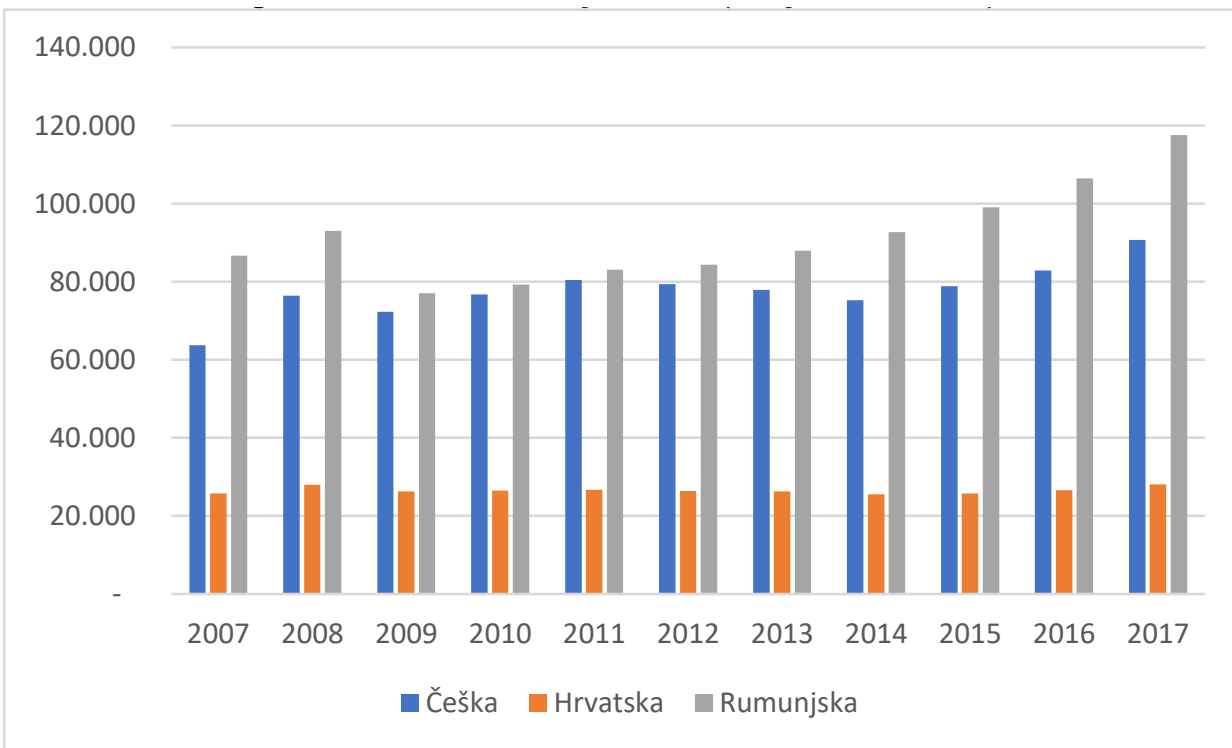

Izvor: EUROSTAT, obradile i prilagodile autorice

Kao što je i očekivano, u promatranim zemljama vidljiv je pad osobne potrošnje u 2009. godini zbog utjecaja krize. Trendovi su oscilirajući, ali dok osobna potrošnja u Rumunjskoj i Češkoj u promatranom vremenskom razdoblju raste, u Hrvatskoj je to puno manje izraženo. U tablici 5 prikazani su indeksi promjena osobne potrošnje.

Tablica 5. Stope promjene osobne potrošnje u odabranim članicama EU-a od 2007. do 2017. godine $u \%$

\begin{tabular}{|c|c|c|c|}
\hline Država/godina & Češka & Hrvatska & Rumunjska \\
\hline 2007. & 9,4 & 9,2 & 28,7 \\
\hline 2008. & 20 & 8,7 & 7,4 \\
\hline 2009. & $-5,4$ & $-5,9$ & $-17,2$ \\
\hline 2010. & 6,2 & 0,7 & 2,9 \\
\hline 2011. & 4,9 & 0,6 & 4,8 \\
\hline 2012. & $-1,3$ & $-1,0$ & 1,5 \\
\hline 2013. & $-1,9$ & $-0,7$ & 4,3 \\
\hline 2014. & $-3,4$ & $-2,8$ & 5,4 \\
\hline 2015. & 4,8 & 0,9 & 6,9 \\
\hline 2016. & 5,1 & 3,3 & 7,4 \\
\hline 2017. & 9,4 & 5,5 & 10,4 \\
\hline
\end{tabular}


Analiza stopa promjene osobne potrošnje kroz navedene godine u 2009. godini ukazuje na znatnije smanjenje osobne potrošnje kod svih triju država u odnosu na 2008. godinu. Češka bilježi smanjenje osobne potrošnje u 2009. godini u odnosu na prethodnu za 5,4 \%, točnije, potrošnja je manja za 4.134 milijuna eura. Hrvatska bilježi smanjenje od 1.650 milijuna eura, što znači da se u 2009. godini osobna potrošnja smanjila za 5,9 \% u odnosu na prethodnu godinu. Rumunjska bilježi najveću promjenu i to je smanjenje potrošnje u 2009. godini za 17,2 \% u odnosu na 2008. godinu, kada je iznosila 77.008 milijuna eura. Nije teško zaključiti da se u tom razdoblju osobna potrošnja naglo smanjila, a razlozi za to su mnogobrojni. Ekonomska kriza svoje djelovanje produbila je upravo 2008. i 2009. godine, što je ostavilo poprilične posljedice na gospodarstva država. Ovdje je važno istaknuti nedostatak novca, koji se najviše manifestirao u smanjenju kreditnih aktivnosti. Zbog nedostatka novca uslijedile su lančane reakcije, naime, pad novčane mase izazvao je pad potražnje, a pad potražnje prouzročio je pad proizvodnje. Kako se kriza i dalje razvijala, nakon pada proizvodnje dolazi do povećanja nezaposlenosti, odnosno pada zaposlenosti i pada raspoloživog dohotka, što je izravno povezano sa smanjenjem osobne potrošnje.

Što se dalje događa s osobnom potrošnjom kroz godine do danas? Za Češku se može reći da ima oscilirajući trend u promatranom razdoblju. To bi značilo da osobna potrošnja na početku bilježi pozitivne stope rasta, iako su male promjene u pitanju, nako $n$ toga 2012. do 2014. godine ponovno je bilježen pad potrošnje u odnosu na prethodne godine, a tek se u 2016. i 2017. godini vidi povećanje potrošnje $u$ odnosu na prethodne godine. Prosjek osobne potrošnje u 2017. godini za Češku iznosi 90.720 milijuna eura, a uspoređujući s iznosom potrošnje u 2008. godini bilježi se rast potrošnje za $18,72 \%$.

Rumunjska kroz promatrano razdoblje bilježi pozitivan trend, što znači da se iz godine u godinu iznos osobne potrošnje povećava. U 2017. godini ona iznosi 117.546 milijuna eura, a usporedba s 2008. godinom bilježi rast potrošnje od $26,31 \%$.

U Hrvatskoj je situacija bila bitno drugačija. Naime, tek u 2016. i 2017. godini može se zamijetiti lagani porast osobne potrošnje u odnosu na prethodne godine. Tome su, osim blagog oporavka gospodarstva, vjerojatno pridonijele i izmjene u sustavu poreza na dohodak iz 2015. godine, što je dovelo do povećanja neto plaća na godišnjoj razini. Zbog povećanja dohotka dolazi do oporavka sklonosti potrošnji koja se uvijek u kriznim razdobljima smanjuje. Ipak, koliko je taj porast malen u odnosu na 2008. godinu pokazuje osobna potrošnja u 2017. godini, koja tada iznosi 28.059 milijuna eura prema 27.984 milijuna eura u 2008. godini. Ukupno povećanje iznosi svega 75 milijuna eura odnosno 0,3 \% što u ukupnom razdoblju govori o stagnaciji umjesto o oporavku osobne potrošnje.

Izdaci za potrošnju kućanstva podrazumijevaju novčanu i naturalnu potrošnju proizvoda i usluga koji služe podmirivanju životnih potreba članova kućanstva (DZS, 2014). Primarne potrebe, poput hrane i pića, stanovanja i potrošnje energenata spadaju u onaj dio potrošnje za koju stanovništvo mora izdvojiti sredstva neovisno o kretanju njegovog raspoloživog dohotka. Veća izdvajanja novčanih sredstava za potrošnju iz raspoloživoga dohotka na luksuzna dobra pokazatelji su razvijenosti, jer će kućanstva više trošiti na takva dobra što je njihov raspoloživi dohodak veći. U tablici 6 prikazana je struktura osobne potrošnje po vrstama dobara za odabrane članice EU-a u 2014. godini. 
Tablica 6. Struktura izdataka za potrošnju u odabranim članicama EU-a u 2014. godini u \%

\begin{tabular}{|l|c|c|c|}
\hline Skupine izdataka & Češka & Hrvatska & Rumunjska \\
\hline Hrana i bezalkoholna pića & 16,3 & 29,5 & 29,4 \\
\hline Alkoholna pića i duhan & 8,3 & 3,3 & 5,7 \\
\hline Odjeća i obuća & 3,3 & 6,8 & 3,4 \\
\hline Stanovanje i potrošnja energenata & 26,0 & 16,2 & 21,5 \\
\hline Pokućstvo, oprema za kuću i redovito održavanje kuće & 5,3 & 4,5 & 4,5 \\
\hline Zdravstvo & 2,5 & 2,9 & 5,9 \\
\hline Prijevoz & 9,7 & 13,0 & 11,3 \\
\hline Komunikacije & 2,9 & 5,5 & 4,1 \\
\hline Rekreacija i kultura & 8,6 & 6,0 & 5,9 \\
\hline Obrazovanje & 0,5 & 1,1 & 2,0 \\
\hline Restorani i hoteli & 8,6 & 2,7 & 2,2 \\
\hline Razna dobra i usluge & 8,1 & 8,5 & 4,1 \\
\hline
\end{tabular}

IzVor: EUROSTAT, obradile i prilagodile autorice

Može se zaključiti da kućanstva iz raspoloživog dohotka najviše izdvajaju za hranu, bezalkoholna pića i stanovanje. Ostale potrebe ovise o visini novčanih primitaka, odnosno, što su oni veći, veći je i standard života. Kada pojedinac ima na raspolaganju određeni novčani iznos, prvo podmiruje osnovne životne potrebe. Tek nakon podmirenja izdataka za kupovinu prehrambenih proizvoda, stanovanja i prijevoza, ostatkom novčanih sredstava može donijeti odluku o potrošnji na, primjerice, odlaske u restorane, frizerske salone, kupnju nakita ili kupnju opreme za rekreaciju, ili pak može odlučiti da ostatak novčanih sredstava uštedi. Kako raste raspoloživi dohodak kućanstva, tako raste mogućnost za potrošnjom luksuznih dobara. Dakle, izdaci za alkoholna pića i duhan, rekreaciju i kulturu, restorane i hotele te razna dobra i usluge ukazuju i na razliku u gospodarskoj razvijenosti između pojedinih država. Za alkoholna pića i duhan u Češkoj je zabilježen najveći udio potrošnje, 8,3 \%, dok je u Rumunjskoj 5,7 \%, a u Hrvatskoj značajno manje, 3,3 \%. Na rekreaciju i kulturu u Češkoj je izdvojeno 8,6 \%, u Hrvatskoj 6,0, a Rumunjskoj 5,9 \%. Na restorane i hotele najviše se troši u Češkoj, 8,6 \%, za kojom Hrvatska i Rumunjska bitno zaostaju s udjelima manjim od $3 \%$. Potrošnja luksuznijih dobara općenito je veća u Češkoj, što je siguran pokazatelj razlike u razvijenosti iživotnom standardu. Zanimljivo je uočiti razlike sobzirom na relativnu visinu izdvajanja za stanovanje i energente koji u Hrvatskoj čine značajno manji udio (16,2 \%) u odnosu na druge dvije promatrane države (26 \% u Češkoj i 21,5 \% u Rumunjskoj). Radi se o izdacima koji su nekad bili više socijalna nego ekonomska kategorija, no dogodile su se brojne promjene na tržištu koje su dovele do toga da je cijena energenata, a sve više i stanovanja, postala usporediva s visokorazvijenim državama. Cijene energenata ovise o mnogo parametara, od raspoloživosti domaćih energenata, energetskog miksa pojedine zemlje, uvozne ovisnosti, do kretanja cijena na globalnom tržištu, no zajednička karakteristika je dugoročni trend rasta cijena. Cijena energenata sve će više odražavati i 
troškove zaštite okoliša zbog trenda dekarbonizacije, kao i poticaje za obnovljive izvore, zbog čega je realno očekivati rast i rastući učinak na osobnu potrošnju.

\section{OSOBNA POTROŠNJA I EKONOMSKI RAST U RH I ODABRANIM ČLANICAMA EU-A}

Budući da je osobna potrošnja najveća komponenta agregatne potražnje i čini najveći udio u BDP-u, nameće se zaključak da je kretanje potrošnje kućanstva izuzetno bitno za svaku zemlju. Analiza koja slijedi želi utvrditi obrasce kretanja osobne potrošnje i ekonomskog rasta te identificirati razlike u odabranim članicama EU-a. Temeljem podataka o osobnoj potrošnji te BDP-u izračunati su udjeli osobne potrošnje u BDP-u koji ukazuju na značajne razlike među analiziranim državama, prikazane u tablici 7.

Tablica 7. Udio osobne potrošnje u BDP-u u odabranim članicama EU-a od 2007. do 2017. godine $u \%$

\begin{tabular}{|c|c|c|c|}
\hline Država/godina & Češka & Hrvatska & Rumunjska \\
\hline 2007. & 46,1 & 58,6 & 67,4 \\
\hline 2008. & 47,4 & 58,1 & 63,7 \\
\hline 2009. & 48,6 & 58,4 & 62,0 \\
\hline 2010. & 49,0 & 58,8 & 63,0 \\
\hline 2011. & 49,1 & 59,6 & 62,6 \\
\hline 2012. & 49,2 & 60,1 & 63,2 \\
\hline 2013. & 49,4 & 60,0 & 61,0 \\
\hline 2014. & 48,1 & 58,8 & 61,7 \\
\hline 2015. & 46,8 & 57,8 & 61,8 \\
\hline 2016. & 47,0 & 57,3 & 62,7 \\
\hline 2017. & 47,3 & 57,6 & 62,6 \\
\hline \multicolumn{2}{|r|}{ Izvor: EUROSTAT, obradile i prilagodile autorice } \\
\hline
\end{tabular}

Temeljem podataka iz tablice 7 evidentno je da osobna potrošnja čini značajan udio u ukupnom BDP-u, što upućuje na zaključak da je to najvažnija domaća komponenta agregatne potražnje. Ipak, razlike su među državama značajne. Tako npr. u Češkoj taj udio u periodu od 2007. do 2017. godine varira između $46,06 \%$ i 49,41 \%, u Hrvatskoj između 57,33 \% i $60,08 \%$, a u Rumunjskoj između 60,98 \% i 67,39\%. Dakle, osobna potrošnja značajna je komponenta BDP-a svih država, te je jasno da promjene u osobnoj potrošnji mogu značajno utjecati na ekonomski rast.

Kako bi se analizirao utjecaj osobne potrošnje na ekonomski rast u svakoj pojedinoj državi u promatranom periodu, uspoređuju se relativni pokazatelji kretanja osobne potrošnje i kretanja BDP-a, s ciljem utvrđivanja međusobne korelacija. Navedena kretanja za svaku pojedinu državu u promatranom periodu prikazana su u sljedećim grafovima. 
Grafikon 3. Usporedba kretanja BDP-a i osobne potrošnje u Češkoj od 2007. do 2017. godine

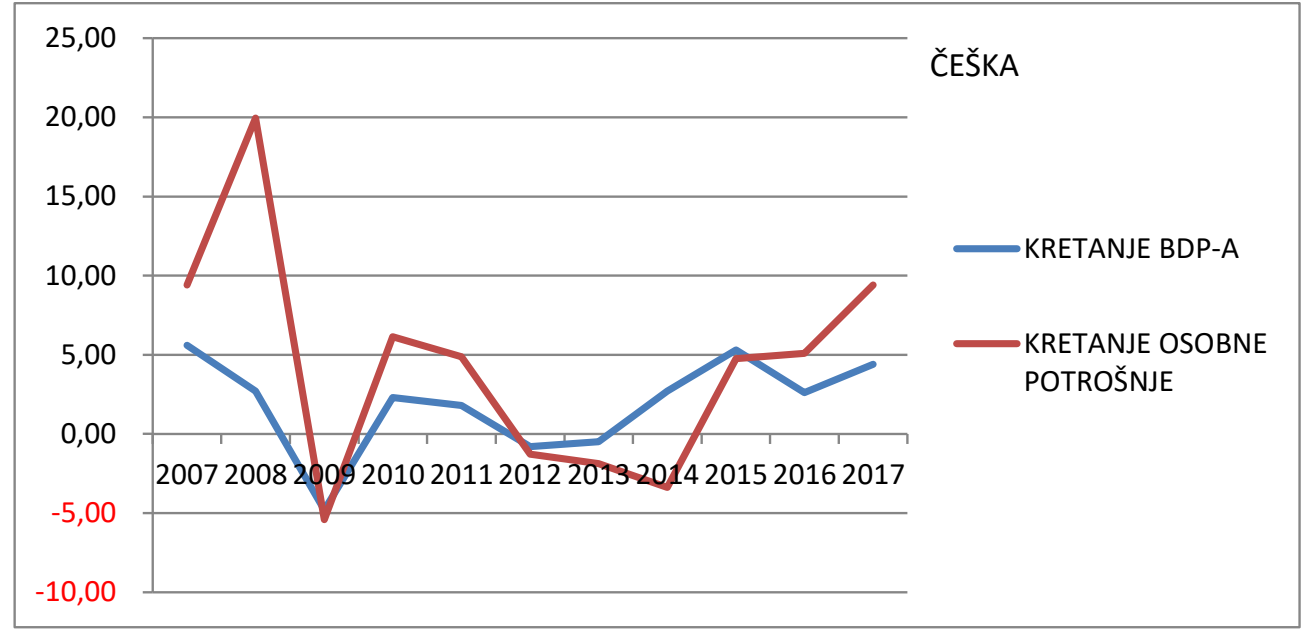

Izvor: EUROSTAT, obradile i prilagodile autorice

Grafički je prikazana usporedba kretanja BDP-a i osobne potrošnje u Češkoj, gdje se može vidjeti da se oscilacije u kretanju BDP-a u promatranom razdoblju uglavnom podudaraju s oscilacijama u kretanju osobne potrošnje. U 2009. godini zabilježen je znatan pad i BDP-a i osobne potrošnje, nakon čega slijedi oporavak kako jednog tako i drugog makroekonomskog pokazatelja.

Grafikon 4. Usporedba kretanja BDP-a i osobne potrošnje u Hrvatskoj od 2007. do 2017. godine

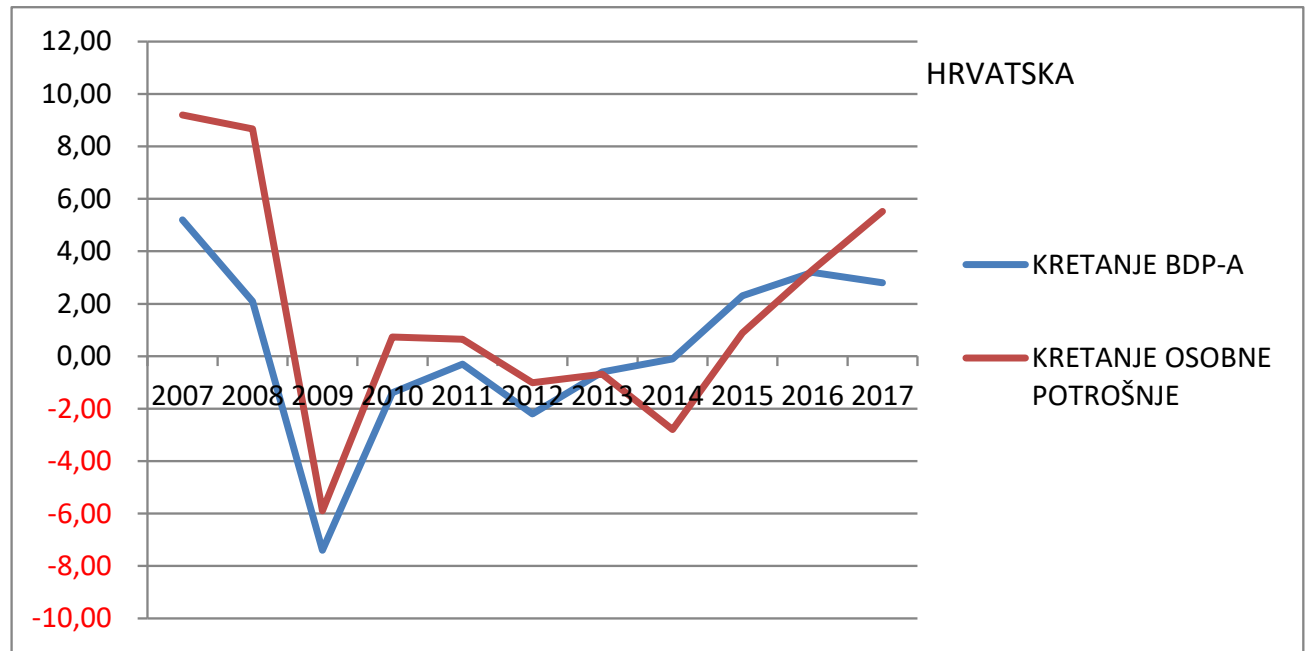

Izvor: EUROSTAT, obradile i prilagodile autorice

Na grafikonu je prikazano kretanje BDP-a i osobne potrošnje u Hrvatskoj, u razdoblju od 2007. do 2017. godine. Smanjenje bruto domaćeg proizvoda u promatranom je razdoblju popraćeno 
padom osobne potrošnje. Od 2014. godine pa nadalje vidi se pozitivno, uzlazno kretanje linija, što znači da se i osobna potrošnja i BDP usporedo povećavaju.

Grafikon 5 prikazuje situaciju u Rumunjskoj, linije osciliraju i u ovisnosti su jedna o drugoj.

Grafikon 5. Usporedba kretanja BDP-a i osobne potrošnje u Rumunjskoj od 2007. do 2017. godine

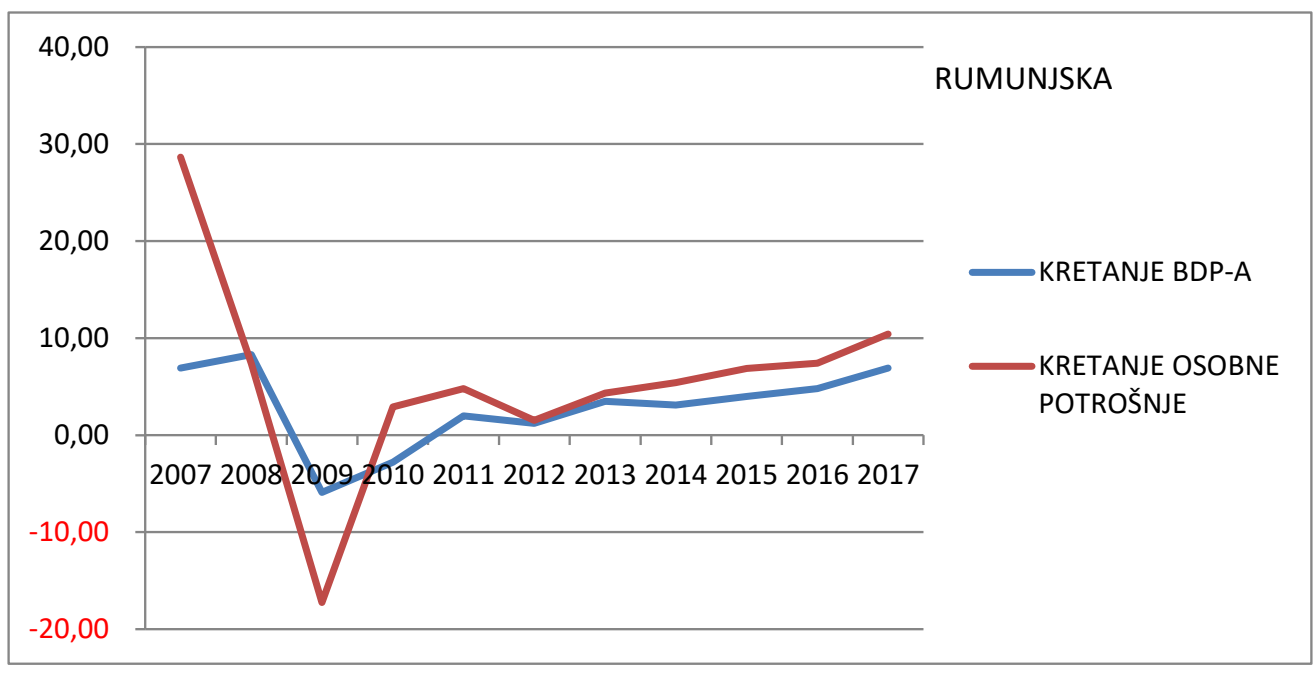

Izvor: EUROSTAT, obradile i prilagodile autorice

Analizom promatranih grafikona može se uočiti kako se kretanja osobne potrošnje i BDP-a u znatnoj mjeri podudaraju, odnosno, jasno je da kretanje osobne potrošnje prati kretanje BDP-a, ali se također može pretpostaviti da postoji i obrnuta veza. Gospodarski oporavak utječe na poboljšanje potrošačkih očekivanja te su kućanstva sklonija potrošnji. Ipak, prethodna analiza ukazuje i na razlike između država. Najmanja podudarnost između promatranih varijabli vidljiva je kod Češke, što znači da je češki gospodarski rast najmanje koreliran s osobnom potrošnjom, odnosno da značajno ovisi o drugim kategorijama potražnje, prvenstveno investicijama i neto izvozu. I sam podatak o najmanjem udjelu osobne potrošnje u BDP-u upravo u Češkoj ukazuje na ekonomski rast koji se manje oslanja na osobnu potrošnju, a više na investicije i izvoznu orijentaciju. Ovakav obrazac gospodarskog rasta znatno je povoljniji nego rast temeljen na osobnoj potrošnji jer rast potrošnje kućanstva uvijek generira rast uvoza, posebice u malim otvorenim ekonomijama kao što su Češka i Hrvatska. Rumunjska je ipak veća ekonomija, mjereno brojem stanovnika, a time i veličinom domaćeg tržišta, pa je kod nje osobna potrošnja relativno važniji generator rasta. Hrvatska je, pak, u najnepovoljnijoj situaciji jer malo domaće tržǐste ne može osigurati učinke ekonomije obujma za domaća poduzeća. Dakle, izvozna orijentacija jedino može biti dugoročni temeljgospodarskog rasta u Hrvatskoj, no rezultati ove orijentacije uvijek ovise i o makroekonomskoj situaciji u državama koje su naša važna izvozna tržišta. Aktualna situacija početka recesije u Italiji sasvim će sigurno nepovoljno utjecati na hrvatski izvoz, iako se konkurentnost našeg izvoza ne mora promijeniti. 
Dakle, kod svih navedenih država postoji značajan utjecaj osobne potrošnje na ekonomski rast. No, u interesu svake pojedine države jest da svoj ekonomski rast, osim na povećanju osobne potrošnje, temelji i na drugim, održivijim generatorima rasta. To su prije svega snažna domaća i inozemna investicijska aktivnost uz povećanje izvozne orijentiranosti države. Navedene komponente imaju izuzetno važnu ulogu u poticanju ekonomskog rasta, što je i konačni cilj svakog gospodarskog sustava.

\section{ZAKLJUČAK}

Osobna potrošnja predstavlja sumu dobara koju kupuju rezidenti neke države i pokazatelj je dostignutog stupnja razvoja i kvalitete života. U vrijeme krize osobna potrošnja pada jer kućanstva zbog makroekonomskih poremećaja mijenjaju svoje potrošačke navike i troše manje. U Hrvatskoj je recesija trajala punih šest godina, što je znatno duže nego u ostalim državama EU-a. Nakon krizne 2009. godine BDP po stanovniku u Češkoj i Rumunjskoj rastao je brže nego u Hrvatskoj, a slična je bila i situacija s osobnom potrošnjom, koja se u tim dvjema zemljama brže oporavljala i brže rasla. Može se zaključiti da je od početka krize do danas osobna potrošnja u Hrvatskoj stagnirala te da je ostala na gotovo istoj razini, za razliku od Češke i Rumunjske. Od promatranih država potrošnja luksuznih dobara relativno je najveća u Češkoj, dok je u Rumunjskoj i Hrvatskoj najviše izražena potrošnja koja služi zadovoljavanju osnovnih životnih potreba, poput hrane i pića te odjeće i obuće. Troškovi za stanovanje i potrošnju energenata čine značajno manji udio, što može upućivati na zaključak da su cijene energenata te stanovanja još uvijek niže nego u usporedivim državama te da možemo očekivati njihov rast u budućnosti.

Analiza kretanja stope promjena BDP-a i stope promjena osobne potrošnje potvrđuje snažnu povezanost tih dviju kategorija, što zapravo i ne iznenađuje, uzme li se u obzir visok postotak osobne potrošnje u kreiranju BDP-a kod promatranih država. Ta je veza donekle snažnija kod Rumunjske, gdje se smjer stopa promjena gotovo podudara. Navedeno potvrđuje osobnu potrošnju kao važnu kategoriju o kojoj treba voditi računa kod donošenja makroekonomskih politika. Analiza je pokazala da je udio osobne potrošnje u BDP-u najmanji u Češkoj, što ukazuje na zaključak da postoje neki drugi pokretači češkog gospodarstva, prvenstveno investicije i neto izvoz. S obzirom na to da su Češka i Hrvatska male otvorene ekonomije koje su usporedive i po dostignutom stupnju razvoja, a imajući u vidu češki gospodarski rast koji je znatno viši nego u Hrvatskoj, može se zaključiti da je model gospodarskog rasta u Češkoj bolji i dugoročno održiviji. Oslanjanje gospodarskog rasta na osobnu potrošnju kao generator agregatne potražnje nije model koji može osigurati održiv rast BDP-a u Hrvatskoj, pogotovo u uvjetima smanjenja broja stanovnika, pa je nužno osigurati poticajan institucijski okvir za rast domaćih i inozemnih investicija te veću izvoznu orijentaciju.

\section{NAPOMENA}

Rad je financiralo/sufinanciralo Sveučilište u Rijeci projektima uniri-drustv-18-27 i uniri-drustv-18-61 


\section{LITERATURA}

Blanchard, O. (2011) Makroekonomija, 5. izd., Zagreb: Mate

Borozan, Đ. (2006) Makroekonomija, 2. izd., Osijek: Sveučilište J.J. Strossmayera u Osijeku

Buturac, G. (2017) Ekonomija u uvjetima visoke zaduženosti: slučaj Hrvatske, Ekonomski pregled, 68 (1), p. 3-31

Denona, Bogović, N. (2002) Dugoročna obilježja osobne potrošnje u Republici Hrvatskoj, Ekonomski pregled, 53 (7-8), p. $622-639$

Jurčić, Lj. (2017) Svjetsko gospodarstvo deset godina nakon početka krize, Ekonomski pregled, 68 (6), p. 655-685

Jurić, J. (2018) Characteristics of personal consumption in Bosnia and Herzegovina, DIEM: Dubrovnik International Economic Meeting, 3 (1), p. 586-596

Keynes, J., M. (1936) The General Theory of Employment, Interest and Money, New York: Harvest

Moore, D., Vamvakidis, A. (2008) Ekonomski rast u Hrvatskoj: mogućnosti i ograničenja, Financijska teorija i praksa, 32 (1), p. $1-28$

Osei, Bonsu, C., Muzindutsi, P.-F. (2017) Macroeconomic Determinants of Household Consumption Expenditure in Ghana: A Multivariate Cointegration Approach, International Journal of Economics and Financial Issues, 7(4), p. $737-745$

Pretorius, C., J., Knox, S. (1995) Private consumption expenditure in the macro-econometric model of the Reserve Bank, Quaterly Bulletin, South African Reserve Bank, https://www.resbank.co.za/Publications/QuarterlyBulletins/ Pages/Quarterly-Bulletin.aspx (17. 12. 2018.)

Rahim, H., A., Bahari, Z. (2018) Keynes' ConsumptionTheory: A Reevaluation According to the Islamic Perspective, GJAT, $8(1)$, p. $7-13$

DZS (2017) Priopćenja i statistička izvješća, Program publiciranja za 2014., Osobna potrošnja, Rezultati ankete o potrošnji kućanstava u 2014.

EUROSTAT (2018) http://appsso.eurostat.ec.europa.eu/nui/show.do?dataset=nama_10_gdp\&lang=en (21. 12. 2018.) 


\title{
PERSONAL CONSUMPTION MOVEMENT - CASE OF SELECTED EU MEMBERS
}

\author{
Vesna Buterin \\ PhD, Assistant Professor, University of Rijeka, Faculty of Economics and Business, Ivana Filipovića 4, \\ 51000 Rijeka, Croatia; e-mail: vesna.buterin@efri.hr
}

\section{Nela Vlahinić Lenz}

PhD, Full Professor, University of Rijeka, Faculty of Economics and Business,Ivana Filipovića 4, 51000 Rijeka, Hrvatska; e-mail: nela.vlahinic.lenz@efri.hr

\section{Natalija Mihaljević}

Student, University of Rijeka, Faculty of Economics and Business, Ivana Filipovića 4, 51000 Rijeka, Hrvatska; e-mail: natalija377@gmail.com

\begin{abstract}
Personal consumption is the largest macroeconomic aggregate with a large impact on economic trends and a share of GDP of about 60\%. The aim of this paper was to determine whether there are significant differences in the movement and structure of personal consumption in Croatia and the two new EU members - the Czech Republic and Romania and to establish patterns of changes in personal consumption in the named countries. The analysis confirmed a strong correlation between personal consumption and GDP, and this correlation is stronger in Romania, where the direction of these two rates of change almost coincides. The previous confirms personal consumption as an important category to be taken into account when adopting macroeconomic policies. The analysis, also, showed that the share of personal consumption in GDP is the smallest in the Czech Republic, suggesting that there are some other Czech economy drivers, primarily investment and net exports. Given that the Czech Republic and Croatia are small and open economies comparable to the level of development, and considering that the Czech economy growth is considerably higher than in Croatia, it can be concluded that the model of economic growth in the Czech Republic is better and more sustainable in the long run. The model of economic growth relying on personal consumption as a generator of aggregate demand is not a model that can ensure sustainable GDP growth in Croatia, especially in terms of population decrease. It is, therefore, necessary to provide a stimulating institutional framework for the growth of domestic and foreign investments and greater export orientation.
\end{abstract}

Key words: personal consumption, gross domestic product, economic growth 